\title{
RISO INVECTIVO VS. RISO ANÓDINO E AS ESPÉCIES DE IAMBO, COMÉDIA E SÁTIRA
}

\author{
JOÃO ANGELO OLIVA NETO* \\ Faculdade de Filosofia, Letras e Ciências Humanas \\ Universidade de São Paulo
}

\begin{abstract}
RESUMO: $O$ artigo tem como objeto demonstrar que em duas passagens da Poética (IV 1448b, 23-40 e V, 1449a, 32-35) Aristóteles assume a existência de dois tipos de riso, o invectivo e o anódino, que correlaciona respectivamente aos gêneros do iambo e da comédia. Partindo da lição de texto e da interpretação da Poética feita por Gerald Else (Aristotle's Poetics, the argument, de 1957) tento demonstrar preferência do filósofo pelo riso anódino e como a diferença de risos é funcional no estabelecimento de espécies no iambo, na comédia e na sátira hexamétrica latina.
\end{abstract}

PALAVRAS-CHAVE: Poética de Aristóteles; riso invectivo; riso anódino; iambo; comédia; sátira.

O objetivo deste artigo é duplo: primeiro ajudar a lembrar que as formas do

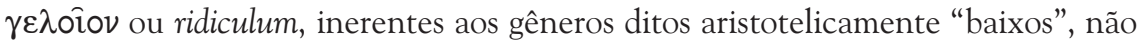
implicam inferioridade ética dos autores, nem inferioridade poética dos poemas, e, segundo, tentar discriminar das várias formas do riso, pelo menos duas modalidades que nos parecem operantes na ramificação interna de três gêneros poéticos, iambo, comédia e sátira hexamétrica. Para tanto, partiremos da leitura de dois trechos na Poética da Aristóteles tendo em mente algumas reflexões capitais de Gerald Else, em Aristotle's Poetics, the argument (1957), que tomamos a liberdade de inserir no próprio corpo do artigo por crer que 50 anos depois devessem talvez estar mais disseminadas entre nós.

A partir da revalorização da retórica e da poética ocorrida nos Estudos Clássicos depois da 2a Guerra, passou ou então voltou a fazer parte do discurso

* Professor Doutor de Língua e Literatura Latina da Faculdade de Filosofia, Letras e Ciências Humanas da Universidade de São Paulo. 
acadêmico a expressão de matiz peripatético "gêneros elevados" para designar a épica heróica, a tragédia, e "gêneros baixos", para a comédia, o drama satírico, a poesia iâmbica e as espécies satíricas, menipéia e luciliânica: a designação não agride o rigor filológico. O que não parece rigoroso é estender a elevação e a baixeza ao caráter e o engenho dos poetas como tais e concluir pela superioridade como agenciadores de discursos, entenda-se como poetas, dos autores de epopéias e tragédias em relação aos autores de comédia, iambos, sátiras etc. Ocorreu que, mercê das ações, caracteres e afetos de seus personagens - elevadas em Ésquilo e baixas em Aristófanes, por exemplo - têm-se entendido que Ésquilo por isso seja considerado ética e poeticamente superior a Aristófanes. Ora, como dos ditos gêneros baixos participa necessariamente, de uma forma ou de outra, o $\gamma \varepsilon \lambda$ oiov, o ridículum (o ridículo, o risível, o riso, ou até, conceda-se, o humor) a conseqüência inevitável, mas equivocada, é que todos os poetas dos gêneros baixos, entenda-se, os poetas dos gêneros risíveis, seriam ética e poeticamente inferiores aos poetas dos

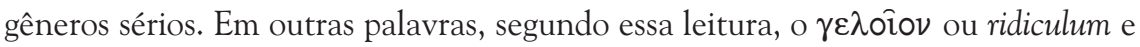
os gêneros que integra parecem excluir não só a excelência ética de seus autores (o que seria absurdo, pela necessária autoridade que deve ter o poeta, quer em Atenas quer em Roma), mas também a excelência póetica deles (como se pela presença do ridiculum e das ações, caracteres e afetos baixos precisassem de menos engenho para compor seus poemas), quando não excluem, por pruridos de ordem espúria, a idoneidade de quem os estuda. A espinhosa questão da superioridade de tal ou qual poeta não se resolve pela comparação singela e isolada das ações, caracteres e afetos de seus personagens, menos ainda se pertencentes a gêneros diversos, mas antes, diga-se provisoriamente aqui, pela efetividade que o agenciamento desses elementos têm em cada poema segundo seu gênero.

O problema tem raiz na Poética de Aristóteles, que quanto aos gêneros risíveis de poesia e ao próprio riso não só apresenta em âmbito grego a mais antiga abordagem teórica, como faz da oposição "sério" / "baixo" o critério mais antigo segundo o qual se separam os gêneros da poesia:

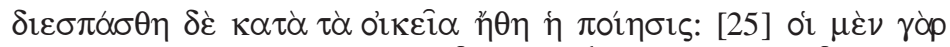

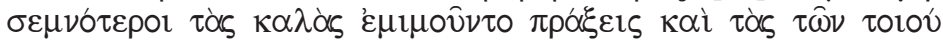

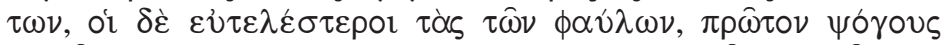

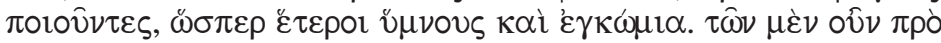

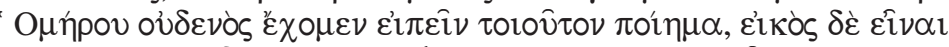

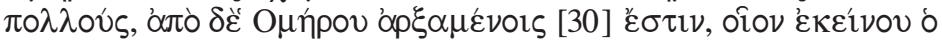

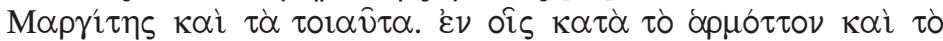

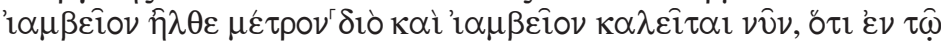

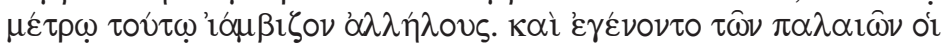




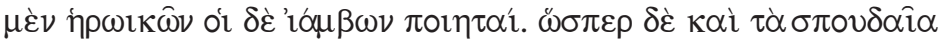

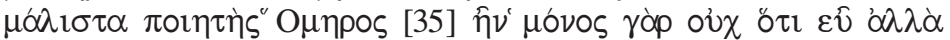

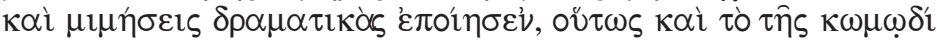

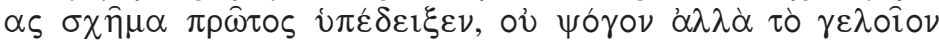

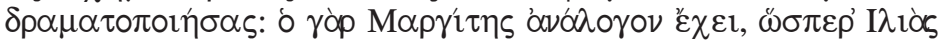

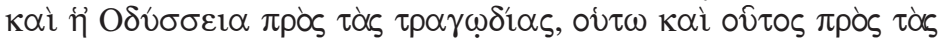
$\kappa \omega \mu \omega \delta$ '́as (Poética, IV, 1448b, 23-40).

Utilizo a tradução de Eudoro de Souza, para ilustrar a discussão:

A poesia tomou diferentes formas, segundo a diversa índole particular [dos poetas]. [25] Os de mais alto ânimo imitam as ações nobres e dos mais nobres personagens; e os de mais baixas inclinações voltaram-se para as ações ignóbeis, compondo, estes, vitupérios, e aqueles, hinos e encômios. Não podemos, é certo, citar poemas deste gênero dos [poetas que viveram] antes de Homero, se bem que, verossimilmente, muitos tenham existido; mas, a começar em Homero, [30] temos o Margites e outros poemas semelhantes, nos quais, por mais apto, se introduziu o metro jâmbico (que ainda hoje assim se denomina porque nesse metro se injuriavam [iámbizon]). De modo que, entre os antigos, uns foram poetas em verso heróico, outros o foram em verso jâmbico. Mas Homero, tal como foi supremo poeta no gênero sério, [35] pois se distingue não só pela excelência como pela feição dramática das suas imitações, assim também foi o primeiro que traçou as linhas fundamentais da comédia, dramatizando, não o vitupério, mas o ridículo. Na verdade, o Margites tem a mesma analogia com a comédia, que têm a Ilíada e a Odisséia com a tragédia.

O problema todo começa no emprego de $\dddot{\eta} \theta \eta$, plural de $\tilde{\eta} \theta$ os, "caráter", adjetivado por o'ıкî $\alpha$, que Eudoro de Souza traduz por "particulares" e ainda deixa entre colchetes "dos poetas", Ana Maria Valente (2004: 43) por "de cada um", Halliwell (1999: 39) por "its creators", Yebra (1974: 137) por "particulares", mas Antonio Riccoboni (apud Yebra, 1974: 137) por proprios mores. Para o problema as reflexões de Gerald Else ${ }^{1}$ (1957) ainda hoje parecem as mais adequadas, por priorizar a in-

1 Eudoro de Souza não apenas conhece o texto de Else, como acolhe na edição que consultamos (Aristóteles, 1966: 112, nota ao §116) a proposta de Else para o’ıعî $\alpha$, ligando o termo a $\pi$ ó́ $\varepsilon \sigma ı \varsigma$, como acrescenta a tradução exegética para o trecho: "a poesia tomou diferentes formas segundo as diversas espécies de caráter que naturalmente lhe pertencem". 
terpretação segundo questões objetivas da própria poesia, o que é mais coerente, pois, com a arte poetica que está a discorrer, em detrimento do caráter do autor. Para Else (pp. 136-137) o’ıعî $\alpha$ não se refere ao caráter dos autores, mas ao caráter dos gêneros de poesia:

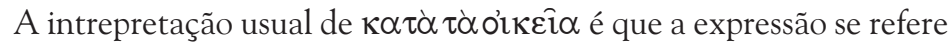
a poetas individuais ("A poesia então separou-se em duas direções, de acordo com o caráter individual dos poetas", Butcher), que, por sua vez, são especificados detalhadamente nas linhas seguintes (ót

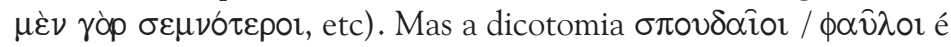
um dado primário, objetivo, que se liga à poesia de modo inerente, como uma representação da vida. É inerente a ela porque a poesia representa homens em (e de) ação e homens tais são necessariamente figuras elevadas ou baixas. Tal especificação não tem nada a ver com temperamente individual. A intrepretação usual deve ser rejeitada por quatro razões:

1. Razão gramatical: é preciso que o'ıкعî seja definido a partir de

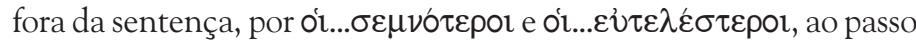
que pode auferir seu sentido mais naturalmente a partir de dentro

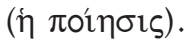

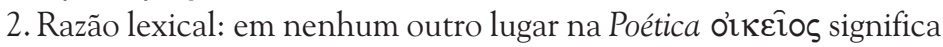
"individual", "particular", mas "próprio de", "inerente a", "pertencente à natureza de".

3. Psicológica: se o temperamento individual fosse fator decisivo, Homero seria um paradoxo insolúvel, para não dizer um monstro, já que escreveu obras-primas nos dois gêneros. Ele era ao mesmo tempo $\sigma \varepsilon \mu \nu \sigma^{\prime} \tau \varepsilon \rho \varsigma$ e $\varepsilon \dot{\nu} \tau \varepsilon \lambda \varepsilon \dot{\varepsilon} \sigma \tau \rho \rho \varsigma$ ?

4. Filosófica: obras de arte são produzidas por artífices na condição de artífices, não na condição de indivíduos. 'É um acidente que o escultor seja Policlito'. Nesta narrativa, os poetas figuram como portadores das causas da poesia. Uma diferenciação permanente deveria ter causas da mesma ordem.

Assim, proponho tomar o'ıкî $\alpha$ no seu sentido usual e natural: "A poesia dividiu-se segundo os caracteres que são inerentes a ela", a

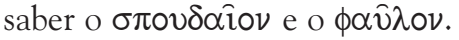

A importância da leitura de Else pode ser avaliada se se pensar, por exemplo, nas composições de autores como Calímaco, Horácio e Sêneca à luz da interpretação "usual" levada, como deveria ser, às últimas conseqüências: como Calímaco pôde compor os Hinos, à maneira homérica, poemas elevados, e os Iambos, ainda que 
estes já não sejam tão invectivos quanto aos arcaicos? Como o mesmo Catulo teria podido compor o poema 97, que é pleno de torpilóquio e o 101, que é prece diante do túmulo do irmão? Como seria possível que o mesmo Horácio que compôs o Carmen Saeculare, as odes civis e os poemas laudatórios a Augusto, que são elevados, tivesse composto os Epodos, em particular o epodo 8, que é abosolutamente baixo, para não mencionar as Sátiras? Como poderia ter Sêneca, a quem se atribui hoje a Apocoloquintose, ter composto também as tragédias?

A vinculação do gênero poema, elevado ou baixo, ao caráter do poeta como pessoa e não como poeta exclui a $\pi \circ \lambda v \varepsilon i \delta \varepsilon \varepsilon 1 \alpha,{ }^{2}$ a possibilidade de cultivar vários gêneros, que Calímaco não só endossava, mas encarecia, e que como se viu vários poetas praticavam.

Seguindo de perto a releitura de Else do mesmo trecho, mas passando ao segundo objetivo deste artigo, propomos entronizar aqui a sugestão do comentador quanto à lição do texto da Poética e apontar como a nova leitura já antecipa a

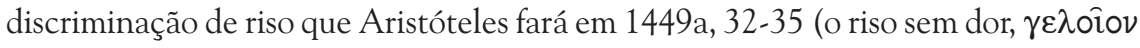

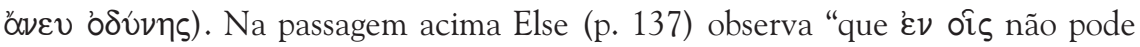

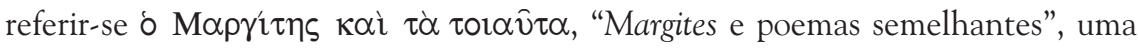

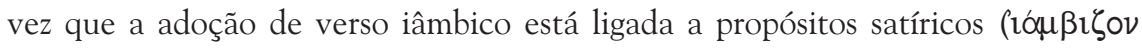
o $\lambda \lambda \hat{\eta} \lambda$ ovs), ao passo que em 1448b, 38 Aristóteles deixa claro que considera o Margites notável porque não era satírico". Assim propõe (p. 138) que a passagem

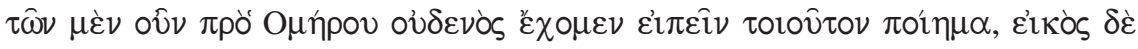

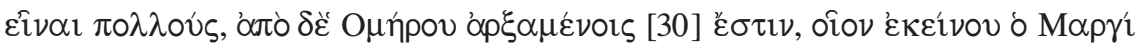

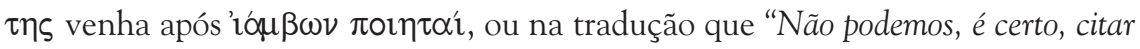
poemas deste gênero dos [poetas que viveram] antes de Homero, se bem que, verossimilmente, muitos tenham existido; mas, a começar em Homero, [30] temos o Margites e outros poemas semelhantes" venha após "outros o foram em verso jâmbico", de modo

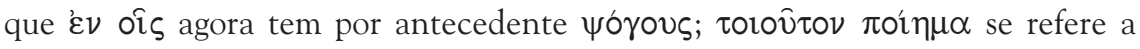

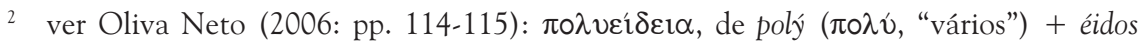

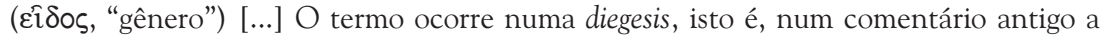

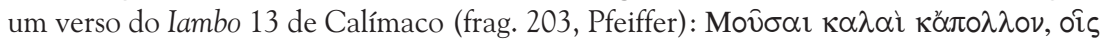
' $\gamma \hat{\omega} \sigma \pi \dot{\varepsilon} v \delta \omega$, "Belas Musas e Apolo, aos quais faço libações". O comentário na Diegesis

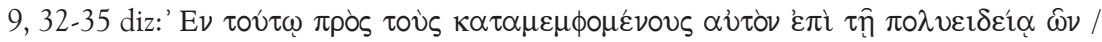

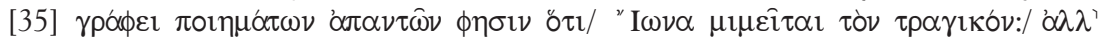

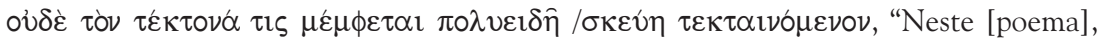
[dirigindo-se] aos que o reprovam pela/ pluralidade de gêneros dos poemas que escreve, [Calímaco] diz / que imita o tragediógrafo Íon: ninguém, de fato, / censura o artífice que faz utensílios multígenos". 


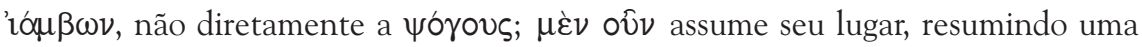
etapa da narrativa e conduzindo à seguinte ('arò $\delta \dot{\varepsilon}$ 'O O

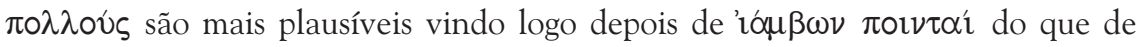

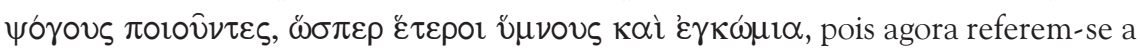
pessoas não a gêneros. Rearranjados, o texto e tradução de Eudoro ficam assim: ${ }^{3}$

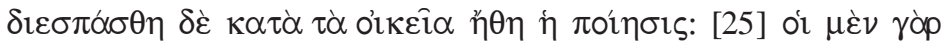

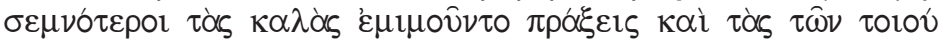

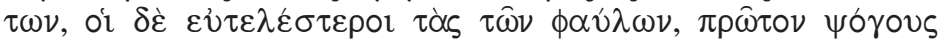

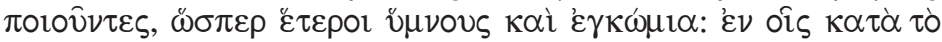

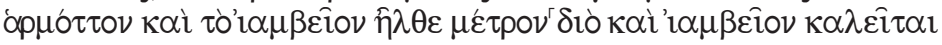

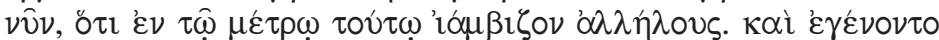

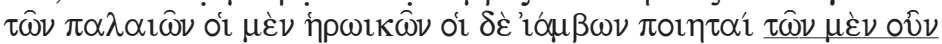

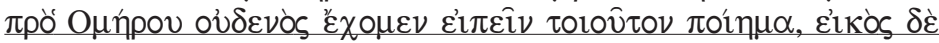

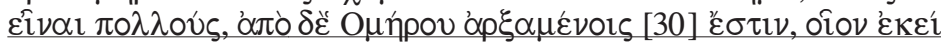

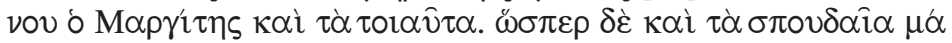

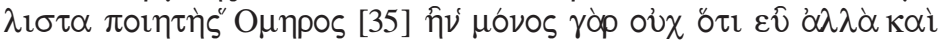

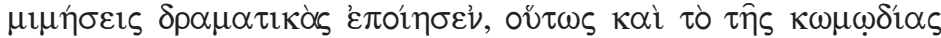

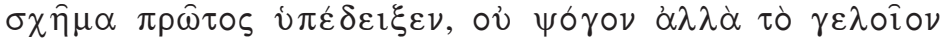

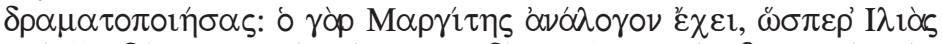

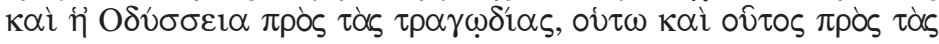
$\kappa \omega \mu \omega \delta$ ícs.

A poesia tomou diferentes formas segundo a diversa espécies de caráter que naturalmente. [25] Pois pessoas de mais alto ânimo imitam as ações nobres e dos mais nobres personagens; e as de mais baixas inclinações voltaram-se para as ações ignóbeis, compondo, estes, vitupérios, e aqueles, hinos e encômios. Nos vitupérios \{ois\} por mais apto, se introduziu o metro jâmbico (que ainda hoje assim se denomina porque nesse metro se injuriavam [iámbizon]). De modo que, entre os antigos, uns foram poetas em verso heróico, outros o foram em verso jâmbico. Não podemos, é certo, citar poetas deste gênero $\{=$ do gênero jâmbico $\}$ entre os [poetas que viveram] antes de Homero,

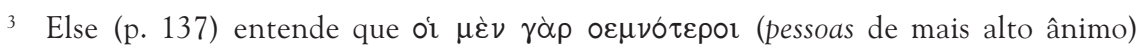

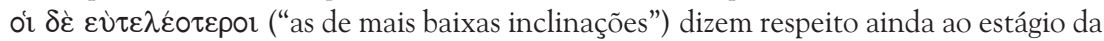

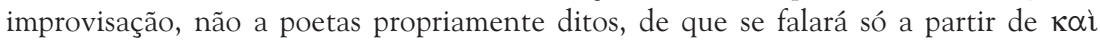

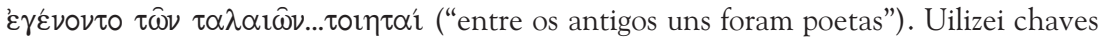
nas adaptações de texto necessárias para diferençiá-las das marcas de Eudoro de Souza, que utiliza colchetes e sublinhei em grego e em português a passagem deslocada para facilitar a compreensão das diferenças que produz. 
se bem que, verossimilmente, muitos tenham existido; mas, a começar em Homero, [30] temos \{o seu próprio, ¿̇кعívov\} Margites e outros poemas semelhantes. Mas Homero, tal como foi supremo poeta no gênero sério, [35] pois se distingue não só pela excelência como pela feição dramática das suas imitações, assim também foi o primeiro que traçou as linhas fundamentais da comédia, dramatizando, não o vitupério, mas o ridículo. Na verdade, o Margites tem a mesma analogia com a comédia, que têm a Ilíada e a Odisséia com a tragédia.

Segundo esta disposição do texto, justamente na disjunção adversativa já men-

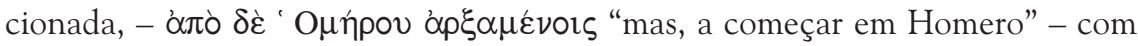

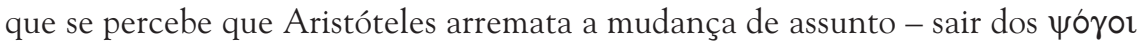
para passar ao Margites é que então, com a autoridade da autoria homérica, o Margites significa, na história dos gêneros em Aristoteles, recusa ao vitupério iâmbico na gênese da comédia, o que corresponde, na sua teoria, não só admitir que há dois tipos de riso, ${ }^{4}$ como também implicar que a excelência homérica

4 Else, pp. 144-145, confirma: "De fato Aristóteles trai aqui, se não um interesse maior na parte cômica, ao menos preocupação maior com ela. Havia pequena evidência documental da história mais antiga dos $\phi \alpha \hat{v} \lambda \alpha$, como ele admite nos seus momentos mais cândidos; pior ainda, o termo e o conceito 'comédia' cobriam dois tipos totalmente diferentes de performance e de humor. Como se poderiam arrolar o Margites e Arquíloco, Epicarmo e Crátino na mesma série, como se fossem todos uma coisa só? As idéias apriorísticas de Aristóteles modelam sua 'história' ao ponto da efetiva distorção.

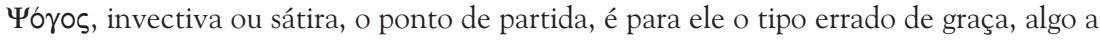

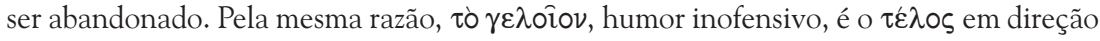
do qual toda a criação cômica se move. $\mathrm{O}$ drama satírico estava ainda engatinhando em Atenas muito tempo depois de poder ter aberto caminho ao tipo correto de farsa, e por outro lado, a verdadeira postura cômica estava embaraçosamente atrasada para fazer sua aparição. Aristóteles agarra-se no Margites com alguma urgência como um dos poucos fenômenos que se ajustavam à sua teoria. Parece de fato que a necessidade de evidência para escorar a teoria obnubilou-lhe o senso crítico, pois o homem que percebeu que eram espúrios alguns ou todos os poemas atribuídos a Orfeu deveria ter sido capaz de detectar que o Margites não era do autor da Ilíada. Mas Aristóteles precisava, para o espírito da comédia, de um impulso remoto o bastante para exercer influência na comédia dórica, e por meio dela, na comédia ática. A única literatura [sic] que oferecia qualquer

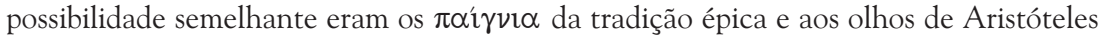
o fato de deterem-se no 'risível' e não na invectiva pessoal era conquista tão elevada,

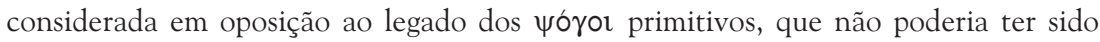
atribuída a ninguém a não ser a Homero. Daí, o divino Homero, supremo poeta no campo da poesia elevada dever levar os louros do gênero baixo também". 
no Margites foi ter estabelecido as bases da comédia por ter acolhido o riso sem dor. ${ }^{5}$

Aristóteles volta à comédia logo a seguir e o que até aqui implicara passa a explicitar, discriminando de fato agora modalidades dois tipos de riso:

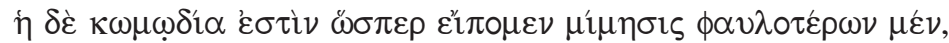

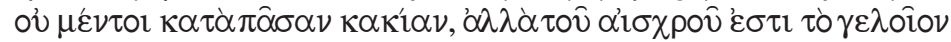

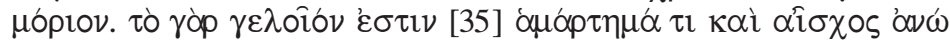

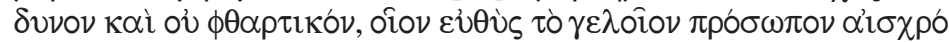

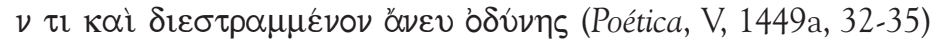

\begin{abstract}
A comédia é, como dissemos, imitação de homens inferiores; não, todavia, quanto a toda a espécie de vícios, mas só quanto àquela parte do torpe que é o ridículo. O ridículo é [35] apenas certo defeito, torpeza anódina e inocente; que bem o demonstra, por exemplo, a máscara cômica, que, sendo feia e disforme, não tem [expressão de] dor.
\end{abstract}

Essa passagem é a mais antiga discriminação no torpe ou no vício, que assim pode ser ou pode não ser ridículo. Associada ao final da passagem anterior, indica-se aqui que para Aristóteles há, de um lado, um riso dolorido e prejudicial: este riso integra os vitupérios ainda não poéticos, que poderíamos inferir que são rituais, e também, mais tarde, a configuração poética deles, que outra coisa não é do que a poesia iâmbica: deve assumir-se aqui a correlação vitupério-riso. E há, de outro

5 Assim procedendo, Aristóteles inevitavelmente desentroniza a figura de Arquíloco, como

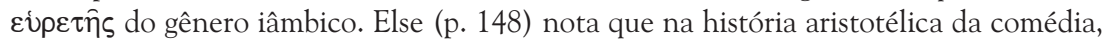
há um grande vazio entre Homero do Margites e o início da comédia e nota que não há lugar para Arquíloco: "Se Arquíloco deve ser posto depois de Homero (e é a única datação plausível) sua obra deverá figurar não mais como a inovação inequívoca em que estamos acostumados a pensar, mas um remanescente desgastado dos $\psi o ́ \gamma o r$ primitivos. Arquíloco não será mais o Homero da poesia iâmbica, mas um seguidor, um renegador da luz, e por isso, sem importância. O paradoxo é surpreendente, mas, creio, corolário inevitável de teoria de Aristóteles, pois não pode coerentemente permitir que o espírito "iâmbico" atinja o clímax depois que Homero já tenha mostrado o caminho

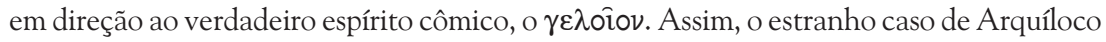
mostra vivamente quão arbitrário e abstrato é o critério de Aristóteles. A própia existência de Arquíloco, todo o caráter de sua obra, era ameaça implícita à história da comédia tal como Aristóteles a via, isto é, um desenvolvimento consistente e contínuo em direção ao ideal de humor inofensivo". Aristóteles não cita Arquíloco na Poética. 
lado, um riso anódino, inocente, sem dor, que teria sido primeiro "dramatizado" por Homero no Margites, que por sua vez, relaciona-se com a origem da comédia, assim como a Ilíada e a Odisséia com a origem da tragédia. A relação consiste precisamente em que no Margites e na comédia há igualdade de objetos (ações, caracteres e afetos baixos) e diferença de modo e de meio. O riso anódino Aristóteles explicita ligar-se ao Margites e por meio dele à comédia, e o riso dolorido o filósofo implica por oposição estar ligado ao vitupério, que já vinculara à poesia iâmbica.

Como está claro, não se trata aqui de endossar acriticamente a teoria aristotélica para reafirmar que na comédia antiga o riso é anódino. Se o riso em Aristófanes é anódino ou deletério não é objeto desse artigo, embora se possa conjecturar que Aristóteles retrospectivamente considere o gênero a comédia, tendo em mente a espécie da comédia nova escrita em grego, como será a de Menandro, que lhe é practicamente contemporânea. O que nos importa em primeiro lugar é dizer que Aristóteles é o primeiro teórico a esboçar dois tipos de riso, um riso vituperioso, que pressupõe por necessidade a invectiva pessoal, e um riso sem vitupério, sem dor, que o filósofo vincula de modo arbitrário à comédia, mas que é exatamente aquele que se encontra documentado em forma narrativa no Hino homérico a Deméter, no episódio de Iambe (vv. 192-205), epônimo do gênero da poesia iâmbica. Esse riso podemos chamar regenerador. Em segundo lugar importanos postular que essa diferença, entendida como conceito, é operante no ulterior estabelecimento de ramificações, por assim dizer, no interior do próprio iambo, a comédia e a sátira. Na comédia e na sátira trata-se mesmo de espécies no interior do gênero. Esboçaremos o problema na comédia e no iambo e nos deteremos na sátira hexamétrica latina.

No caso do iambo, não fosse por admitir a existência de ramificações, com extrema dificuldade poder-se-ia associar no mesmo gênero o vitupério, mesmo quando risível, (mediante o qual fontes antigas e comentadores modernos caracterizam o gênero) àquele riso com que Iambe traz Deméter de volta à vida. Para que a eponímia Iambe / iambo tenha alguma relevância filológica, é necessário, primeiro, que o vitupério iâmbico seja risível, e, segundo, que haja, pois, dois tipos de riso. No riso regenerador de Deméter ninguém é injuriado, não se ri a expensas de nenhuma figura que justa ou injustamente ali se torna vítima: há riso, motivado por obscenidade que seja, mas não há derrisão. Muito da poesia iâmbica arcaica que restou é vituperiosa e eventualmente risível, mas alguns fragmentos pressupõem dimensão festiva no âmbito da mesma Deméter e de Dioniso (West: 1974, 24-25), em particular o fragmento 215 , em que ocorre por primeiro o termo ' $1 \alpha \mu \beta$ s: 


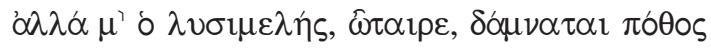

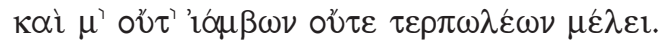

mas quebra-membros, ó companheiro, doma-me o desejo e de iambos e de festas já não cuido.

West (1974: 25) sobre o fragmento observa:

"^ $\alpha \mu \beta$ ß tem algo relacionado a $\tau \varepsilon p \pi \omega \lambda \alpha$, "festa" e tem algo em que Arquíloco poderia ter algum interesse, se é que não estava ofendido. São mais que apenas versos, são uma ocasião. Seus poemas conhecidos como iambos devem ter sido assim chamados porque foram associados a tais ocasiões.

No gênero cômico, tal como no iâmbico, mais de um elemento e de vária ordem está na raiz da diferença entre a comédia antiga e a comédia nova, mas tendo em vista a importância estrutural do riso como afeto intrínseco ao gênero, a exclusão do vitupério e do que riso que produzisse é das mais notáveis. ${ }^{6}$ Sabemos que na comédia nova o corpo coletivo é a familía no espaço da casa, em vez dos cidadãos no espaço da cidade, como em Aristófanes. Não obstante, o ataque que agora "o pai de comédia" (personatus pater), como diz Horácio (Sat. 1, 10, 56), e personagens similares recebem, o riso que daí advém, correlato ao desenlace pacificador, engendra a salvação, a regeneração do corpo coletivo por cura e

6 Degani (apud De Martino, F., Vox, O, 1995: 4-5) afirma: Na iambografia arcaica podemse de fato distinguir dois filões substancialmente análogos aos que caracterizam o gênero literário [sic] que se deve considerar o mais vizinho dela, que é a comédia. Nascidos de modo e circunstâncias afins, com efeito não eram poucos os elementos que iambo e comédia tinham em comum, de natureza não apenas formais (a começar pelo metro) mas também substanciais. Temas e conteúdos são amiúde os mesmos: descrição de ambientes esquálidos e personagens vulgares, apelo insistente ao ventre e ao sexo (donde elencos de alimentos e glutoneria, de um lado, e obscenidade, de outro), e ainda escatologia, turpilóquio, paródia mítica e literária [sic], ataque pessoal e político, derrisão de categorias bem definidas (profetas, médicos, avarentos, pintores, escultores e outros). É de notar, porém, que toda a comédia encontra na iambografia seus modelos: não só a que é intérprete e herdeira das antigas falofórias, mas também aquele filão - representado na Sicília por Epicarmo, na Ática por Crates e depois por Menandro - que renunciou à invectiva e à escrologia, apegando-se a temas mitológicos, $\mu \hat{v} \theta 0$ r ligeiros, toques paródicos, sentenças agudas, e mais tarde à representação da vida cotidiana". In: De Martino, F., Vox, O., p. 4-5. 
conseqüente reintegração do membro nocivo e já não mais, como ocorre em algumas peças de Aristófanes (Lâmaco n'Os acarnninses e Paflagônio n'Os cavaleiros) pelo rebaixamento a uma condição vil, que na verdade significa ablação, extirpação, simbólica que seja, desse membro. Como na medicina antiga, purifica-se o corpo ou pela ablação da parte doente ou pela sua cura e reintegração à inteireza do corpo. ${ }^{?}$

A ramificação análoga ocorrerá na sátira latina nas espécies luciliânica e horaciana, quer diretamente, o que suporia a discutível recepção da própria Poética, quer indiretamente, supondo-se no tempo de Horácio o mais provável debate de idéias concernentes à questão. Como se verá adiante, Horácio por duas vezes trata da relação do riso com a comédia antiga, e se parece contradizer-se quanto a que tipo de riso ela continha, é inequívoco que assume a existência de pelo menos esses dois tipos e o fato de que o riso anódino será responsável, entre outros fatores, pelo que passou a ser a subespécie horaciana da sátira hexamétrica.

Na sátira 1, 1, o símile com que Horácio admite o riso é exemplar (vv. 23-27):

Praeterea ne sic, ut qui iocularia, ridens

percurram - quamquam ridentem dicere uerum

quid uetat? Vt pueris olim dant crustula blandi

doctores, elementa uelint ut discere prima;

sed tamen amoto quaeramus seria ludo

Além disso, não devo sobre esses assuntos discorrer

rindo tal como quem conta anedotas - embora o que proíbe alguém

de, rindo, dizer a verdade, tal como, às vezes, mestres gentis, que

dão biscoitos às crianças

para que queiram aprender as primeiras letras?

Porém, brincadeiras à parte, examinemos as coisas sérias.

7 "O tema do cômico é a integração da sociedade: toma usualmente a forma da incorporação, nela, de uma personagem fundamental". Em Frye (1984: 49). E também (p. 165) "A tendência da comédia é incluir tanta gente quanto possível em sua sociedade final: as personagens obstrutoras são mais amiúde reconciliadas, ou convertidas, do que simplesmente repudiadas" (itálicos do original). A afirmação de Frye é verdadeira quanto a qualquer comédia nova, de Menandro, Terêncio e Plauto, mas não a qualquer comédia de Aristófanes. 
Paradigmática, a passagem mostra a oposição do jocoso (multiplicado em três termos: iocularia, de iocularium, -i, "anedota", cognato de iocus, -i, "gracejo"; ridens, particípio de ridere, "rir", e ludo, de ludus, -i, "brincadeira") às coisas sérias, seria (neutro plural do adjetivo serius, - $-a,-u m$ ), depois de permitir a utilização do riso com fins veristas, dicere uerum. Entretanto, a relação do jocoso com o sério nesta passagem de Horácio é ambígua, e é bem a ambigüidade que a faz notável. Ali, o jocoso é primeiro inserido por meio de autoproibição da persona satírica (subjuntivo negativo de exortação ne percurram), comparada também a quem faz piadas (pelo símile ut qui iocularia [dicit / dicunt]), para depois vir concedido pela oração propriamente concessiva (quamquam) e ratificado pela pergunta retórica quis uetat, que equivale a nemo uetat ("ninguém proíbe"). Um segundo símile (Vt pueris...), que enaltecia pedagogicamente a eficácia do riso por compará-lo aos presentes de professores gentis, é interrompido pelo tom corretivo da persona satírica, que retoma então o assunto sério. Percebe-se, em suma, que Horácio pede permissão, concessão, digamos assim, ao gênero satírico, para acrescentar uma certa jocosidade, que, portanto, não é, em princípio, própria deste gênero. Na sátira 4, vv. 1-10, a questão prossegue:

Eupolis atque Cratinus Aristophanes poetae atque alii, quorum comoedia prisca uirorum est, siquis erat dignus describi, quod malus ac fur, quod moechus foret aut sicarius aut alioqui famosus, multa cum libertate notabant. Hinc omnis pendet Lucilius, hosce secutus mutatis tantum pedibus numerisque, facetus, emunctae naris, durus componere uersus; nam fuit hoc uitiosus; in hora saepe ducentos, ut magnum, uersus dictabat, stans pede in uno

Êupolis, Cratino, Aristófanes, poetas, e outros homens a que pertence a comédia antiga, sempre que alguém era digno de ser censurado por ser mau, ladrão, adúltero, sicário e, por qualquer outra razão, famigerado, eles o maculavam com grande franqueza.

Daí provém todo Lucílio; ele os seguiu mudando só pés e metros, espirituoso,

de ar refinado, duro ao compor seus versos, pois nisso foi vicioso: numa hora, amiúde ditava duzentos versos, 
como se fosse algo grandioso, num só pé.

No passo Horácio vincula Lucílio, criador da sátira hexamétrica latina, aos comediógrafos da comédia ática antiga e o vínculo é duplo: há em ambas a indicação dos elementos viciosos e a permissão de alvejá-los com liberdade (libertas, "liberdade de falar", "falta de freio"), isto é, com grande franqueza, que significa vitupério e o riso vituperioso. Horácio insinua o jocoso na vinculação entre comédia e sátira e na menção, brevíssima, de facetus, 8 "faceto", "cheio de facécia", "espirituoso". É tão breve o registro quão técnico é o termo: facetus, se não adentra ainda o risível, já o toca de soslaio. Adiante, no diálogo com o fictício interlocutor na sermocinatio, este faz ressalvas contra a verve do poeta satírico (vv. 34-38), e o cerne da ressalva é precisamente a agressividade da derrisão:

Faenum habet in cornu, longe fuge; dummodo risum excutiat sibi, non hic cuiquam parcet amico, et quodcumque semel chartis illeuerit, omnis gestiet a furno redeuntis scire lacuque et pueros et anus.

[o poeta satírico] tem feno no chifre [i. e. vem identificado como, em Roma, os touros bravios para prevenir transeuntes] e tu, foge para longe: contanto que faça eclodir em si mesmo o riso, não poupará nenhum amigo e tudo aquilo que uma vez tiver lavrado no papel ansiará que saibam todos, meninos e idosas, enquanto voltam do forno e da fonte.

Agressivo como touro do qual é mister fugir, o poeta satírico não poupará nem mesmo os amigos, desde que vingue produzir em si mesmo ou para seu deleite o riso, que outro não pode ser senão o de escárnio, o vituperioso. Pouco à frente na mesma sátira, o interlocutor lhe diz: laedere gaudes [...] / et hoc studio prauos facis (vv. 78-79, "tu te comprazes em ferir [...] e, perverso, o fazes de propósito"), com

8 Facetiae são concretamente atitudes, em geral ditos, cheios de vivacidade; facetus, quem a tem, donde infacetus e inficetus; ver Catulo, 12, 9; 36, 19; 43, 8; 50, 8. Quintiliano (Instituiões oratórias 6, 3, 19) assere: Facetum quoque non tantum circa ridicula opinor consistere. Neque enim diceret Horatius facetum carminis genus natura concessum esse Vergilio, "e facetum não considero aquilo que diga respeito ao riso, pois Horácio não diria que um gênero faceto de poesia teria sido concedido a Virgílio pela natureza”. 
que torna patente a acusação por ratificar a destrutividade do riso. A persona satírica então defende-se alegando ${ }^{9}$ (vv. 81-85):
Absentem qui rodit amicum
qui non defendit alio culpante, solutos
qui captat risos hominum famamque dicacis, ${ }^{10}$
fingere qui non uisa potest, comissa tacere
qui nequit, hic niger est; hunc tu, Romane, caueto
Quem corrói um amigo ausente,
quem não o defende quando outro o acusa,
quem busca obter a gargalhada dos homens e a fama de mordaz,
quem é capaz de inventar coisas que não viu,
quem não consegue calar o que lhe foi confiado, este é de espírito
negro; contra este, romano, tu deverás acautelar-te.

Como dissemos, Horácio não chega ao limite de propor a substituição do riso satírico, que em princípio trazia consigo algo de agressão deletéria, por aqueloutro anódino, mas, segundo pensamos, postula a possibilidade de coexistirem. Assim, se é recusada a solitária presença de um riso apenas corrosivo (ver acima v. 81 rodit, de rodere, "corroer"), é de esperar que defenda para a sátira certa liberdade derrisória contra o vicioso, função precípua do gênero, verificável ainda pela fala de Horácio, aqui provavelmente por trás da máscara satírica, em excertos logo à frente dos já mencionados (vv. 91-93 e vv. 103-106):

ego si risi, quod ineptus

pastillos Rufillus olet, Gargonius hircum,

linidus et mordax uideor tibi?

\section{liberius si}

9 Acreditamos que essa fala pertença à persona satírica, não ao interlocutor. Todavia, ainda que assim fosse, Horácio continuaria a propor acrescentar-se ao riso deletério, originariamente solitário na sátira hexamétrica, o riso sem dor.

10 dicacis, genitivo de dicax, "mordaz", "o que diz ditos mordazes". Comentando a qualidade por meio do cognato dicacitas, Quintiliano (Instituições oratórias, 6, 13, 21) confirma o cunho eversor do riso: Dicacitas sine dubio a dicendo, quod est omni generi commune, ducta est, proprie tamen significat sermonem cum risu aliquos incessentem, "Dicacitas ["dicacidade", "mordacidade"] sem dúvida provém de "dizer", que é comum a todo gênero [de risível], mas propriamente significa o discurso que, com riso, ultraja algumas pessoas". 
dixero quid, si forte iocosius, hoc mihi iuris

cum uenia dabis; insueuit pater optumus hoc me

ut fugerem exemplis uitiorum quaeque notando.

Eu, se ri porque Rufilo, inepto,

tem hálito que cheira a pastilhas, e Gargônio, hálito que cheira a

bode,

pareço-te invejoso e mordaz?

Se eu com maior liberdade,

se talvez mais jocosamente disser algo, um pouco desse direito

e indulgência me darás; a isso meu pai, homem excelente, habituou-me,

de modo que, ressaltando com exemplos cada um dos vícios, eu os

evitasse.

Na sátira 1,10 , peça nitidamente prescritiva, articulada assim com a 1,4 , que temos lido, Horácio, admitindo já ter tratado da matéria, torna a ela, e ora não só patenteia as duas modalidades do riso, como preceitua incluir-se no gênero satírico a modalidade anódina, que aqui vincula à comédia (vv. 1-17):

Nempe incomposito dixi pede currere uersus

Lucilii. Quis tam Lucili fautor inepte est,

ut non hoc fateatur? "At idem, quod sale multo

urbem defricuit, charta laudatur eadem".

Nec tamen hoc tribuens dederim quoque cetera; nam sic

et Laberi mimos ut pulchra poemata mirer.

Ergo non satis est risu diducere rictum

auditoris; et est quaedam tamen hic quoque uirtus.

Est brenitate opus, ut currat sententia neu se

impediat uerbis lassas onerantibus auris,

et sermone opus modo tristi, saepe iocoso,

defendente uicem modo rhetoris atque poetae,

interdum urbani, parcentis uiribus atque

extenuantis eas consulto. Ridiculum acri

fortius et melius magnas plerumque secat res.

Illi, scripta quibus comoedia prisca uiris est,

hoc stabant, hoc sunt imitandi. 
Falei sim que correm com pé desregrado os versos

de Lucílio. Quem é tão ineptamente partidário de Lucílio

que não admita isso? 'Mas ele mesmo, por ter com muito sal

esfregado a cidade, é louvado na mesma página.'

Mas não é porque lhe atribuí esse mérito que eu deveria também ter-lhe concedido outras coisas; pois assim

também teria de admirar os mimos de Labério como belos poemas.

Logo, não basta com o riso fazer contrair-se o ricto [isto é, arreganhar a boca]

do ouvinte, se bem que haja aí certa virtude.

É preciso brevidade para que o pensamento corra e não

tropece em palavras que pesem sobre ouvidos cansados,

e a fala é preciso ora grave, amiúde jocosa,

tal que sustente ora a parte do orador e a do poeta,

e às vezes a de um homem urbano que poupa suas forças ou

as extenua de propósito. O ridículo, mais do que o acerbo,

na maioria das vezes resolve mais fortemente e melhor as grandes

questões.

Era nisso que aqueles homens que escreveram a comédia antiga se regiam e nisso devem ser imitados.

(Destaques nossos).

Os extraordinários ${ }^{11}$ preceitos positivos desse entrecho acentuam o que pretendemos estabelecer: não bastar (non satis est) para a sátira, segundo Horácio, o escárnio, aqui referido pela perífrase risu diducere rictum, literalmente "contrair o ricto pelo riso", isto é, "arreganhar a boca". Como se buscasse captar certa benevolência para a inovação que vai efetuar, antes de propor enfim o acréscimo do riso inocente ao escárnio satírico, prestes então a perder a primazia, Horácio deixa clara a

11 São extraordinários porque, em vez desfiar censuras, a sátira, no trecho, arrola conselhos; ver Marcos Martinho dos Santos (1997: 136): "Se lá, porém, [Epistolas e Sátiras] se distinguem por serem estas sermo ["conversa", "diálogo"] propriamente dito, e aquelas metade de um, aqui, distinguem-se, a meu ver, por se aterem as Epístolas, precipuamente, à persuasão, bem entendido, da uirtus, e as Sátiras, à dissuasão, bem entendido do uitium”. As sátiras 1, 10 e 1, 4, por eleger, como vicioso, procedimentos poéticos de um poeta satírico, são auto-referentes, isto é, tratam da própria sátira como gênero. Daí decorre a semelhança da passagem com o teor prescritivo da Arte poética. 
existência também (quoque) nesse riso deletério de certo "mérito", certa "virtude" (quaedam uirtus), que consiste, efetivamente, em conter a carga de punição necessária e obrigatória do gênero satírico. $O$ poder corretivo da sátira fora referido na passagem pela expressão sale multo urbem defricuit, "esfregou com muito sal a cidade" ${ }^{12}$ que, referente a Lucílio, designa o gênero satírico originário em sua função profilática. A permanência na sátira dessa virtude necessária garante-lhe, mesmo alterada, sua continuidade como gênero. Assim, obtida a certeza de que o gênero persevere, Horácio prescreve-lhe o acréscimo do riso anódino (que nessa passagem é relacionado com o riso cômico), indicado pelos termos iocoso e ridiculum e referendado pelo exemplo dos varonis autores (uiris) da comédia antiga. A inclusão do riso inocente, mirando mitigar o sarcasmo próprio do riso satírico, opera menos na matéria e fim satíricos - vale dizer, no indiciamento e correção do vicioso - do que no público, ou para ser exato, na sua capacidade de atenção. A inclusão do riso anódino pretende assim vingar no discurso o deleite retórico. Por isso, a irrisão sem dor não só é proposta logo após a prescrição de brevidade como também é o elemento com o qual deve vir alternado o discurso grave. A gravidade - referida pelos termos sermone tristi e acri - e já associada a pesantes palavras (uerbis onerantibus), segundo o poeta, não resolve (secat, de secare, literalmente "parte”, "corta”) a grandeza das questões, melhor do que o jocoso, cuja inserção na sátira quer alcançar também o convencimento do ouvinte, mouere, que, caro a Quintiliano nas questões forenses, o fará muito provavelmente aludir à prescrição do ridiculum horaciano. ${ }^{13}$ Pode-se dizer em suma que Horácio, sem desfigurar a sátira, tornou-a menos agressiva com importar-lhe a derrisão indolor.

12 aqui defricare pontua com precisão a limpeza decorrente do ato não muito delicado de "esfregar" (de ex + fricare), ofício do poeta satírico. Sale é sinédoque da pureza conservante do sal e, sobretudo, termo técnico indicativo do modo picante, saboroso com que o poeta desempenha esse ofício: o sabor é justamente o riso; ver Quintiliano, $6,3,18$, salsum.

13 Huic diuersa uirtus, quae risum iudicis mouendo et illos tristes soluit adfectus et animum ab intentione rerum frequenter auertit et aliquando etiam reficit et a satietate uel fatigatione renouat. [...] Cum uideatur autem res leuis et quae ab scurris mimis, inspicientibus denique saepe moueatur, tamen habet uim nescio an imperiosissimam et cui repugnari minimi potest. Erumpit etiam inuitis saepe, nec uultus modo nec uocis exprimit confessionem, sed totum corpus ui sua concutit. Rerum autem saepe (ut dixi) maximarum momenta uertit. (Institutiones oratoriae, 6, 3, 1 e 6, 3, 9). "Agora [trato de] uma outra virtude, que, movendo o riso do juiz, desfaz as afecções pesadas, com freqüência desvia sua atenção das acusações da causa e às vezes até o torna refeito, revigorando-o do enfado e do cansaço. [...] Embora pareça coisa ligeira, amiúde movida por bufões, mimos e tolos, o riso, porém, possui 
É precisamente a ausência de dolor na sátira de Horácio o que a difere da sátira de Juvenal, que, um século depois, desconsiderando as prescrições de Cícero ${ }^{14}$ e Quintiliano, ${ }^{15}$ volta a cumprir o modelo de Lucílio. Por brevidade, veja-se o mínimo preceito (1, 1, vv.165-168):

uma força que julgo imperiosíssima, à qual é difícil resistir. Com freqüência, irrompe até contra nossa vontade e extrai nossa confissão não só pelo rosto e pela voz mas também agita todo o corpo com sua força. Como disse, o riso reverte os momentos culminantes, como quando quebra o ódio e a raiva". A alusão, pensamos, apóia-se no uso, aqui e em Horácio, de uirtus, de tristes, na menção de mimus e da semelhança entre secare e frangere ("cortar" e "quebrar") referentes às "grandes questões", momenta maximarum aqui, e magnas res em Horácio.

14 Cícero no tratado Sobre os deveres (De officiis) 1, 136, deixa clara a intenção corretiva por inclusão [...] maxime curandum est ut eos quibuscum sermonem conferemus et uereri et diligere uideamur. Obiurgationes etiam nonnumquam incidunt necessariae, in quibus utendum est fortasse et uocis contentione maiore et uerborum grauitate acriore, id agendum etiam ut ea facere uideamur irati. Sed ut ad urendum et secandum sic ad hoc genus castigandi raro inuitique ueniemus nec umquam nisi necessario, si nulla reperietur alia medicina; sed tamen ira procul absit, cum qua nihil recte fieri, nihil considerate potest. Magnam autem partem clementi castigatione licet uti, grauitate tamen adiuncta, ut seueritas adhibeatur et contumelia reppelatur, atque illud ipsum quod acerbitatis habet obiurgatio, significandum est, ipsius id causa, qui obiurgetur, esse susceptum [...], "Importa muito que as pessoas com quem estamos falando percebam que lhes temos respeito e consideração. E há ocasiões em que é necessário dar alguma repreensão, levantar a voz e falar um pouco asperamente, e até mesmo agir, de modo a parecer que estamos irados. Mas só raramente e contra a vontade chegaremos àquele gênero de castigo, e nunca o faremos a não ser se for inevitável e se não se achar outro remédio, tal como quando é necessário amputar e cauterizar. Mas repito que se deve reprimir a ira, com a qual não pode haver justiça nem acordo. As repreensões leves são as que quase sempre convém usar; é necessário que haja nelas certa gravidade, sem nos recearmos de insultos. E todo rigor que houver nessas ocasiões é preciso mostrar que é para benefício de quem se repreende".

15 Instituições oratórias, 6, 3, 1 e 6, 3, 9, Huic diuersa uirtus, quae risum iudicis mouendo et illos tristes soluit adfectus et animum ab intentione rerum frequenter auertit et aliquando etiam reficit et a satietate uel fatigatione renouat. [...] Cum uideatur autem res leuis et quae ab scurris mimis, inspicientibus denique saepe moueatur, tamen habet uim nescio an imperiosissimam et cui repugnari minimi potest. Erumpit etiam inuitis saepe, nec uultus modo nec uocis exprimit confessionem, sed totum corpus ui sua concutit. Rerum autem saepe (ut dixi) maximarum momenta uertit, ut cum odium iramque frequentissime frangat, "Agora [trato de] uma outra virtude, que, movendo o riso do juiz, desfaz as afecções pesadas, com freqüência desvia sua atenção das acusações da causa e às vezes até o torna refeito, revigorando-o do enfado e do cansaço. [...] Embora pareça coisa ligeira, amiúde movida por bufões, mimos e tolos, o riso, porém, possui uma força que julgo imperiosíssima, à 
ense uelut stricto quotiens Lucilius ardens

infremuit, rubet auditor cui frigida mens est

criminibus, tacita sudant praecordia culpa.

Inde irae et lacrimae.

toda vez que, como que agarrando a espada, inflamado, um Lucílio brame, enrubesce o ouvinte cuja mente se enregela

pelos crimes, o peito sua da secreta culpa:

daí a ira e as lágrimas.

No passo, Lucilius por antonomásia significa "autor de sátira" e, designando especificamente o próprio Juvenal, acusa sua filiação ao gênero da sátira hexamétrica. A imagem de vingador inflamado, que, espada na mão, produz no ouvinte afecções sintomáticas dos crimes e sua culpa, opõe-se à busca horaciana de, com o riso, evitar a gravosa acerbidade. Juvenal pode assim documentar alguns aspectos da sátira de Lucílio dos quais Horácio se afastou. Em Juvenal, riso e ridículo podem provir da exclusão que, naquela sociedade estratificada e nos que são como que seu porta-voz, antes imputa ao pobre senão a culpa ao menos o fardo de sua pobreza do que acusa as condições sociais que o empobrecem (1, 3, vv. 147-153):

Quid quod materiam praebet causasque iocorum omnibus hic idem, si foeda et scissa lacerna, si toga sordidula est et rupta calceus alter pelle patet, uel si consuto uulnere crassum atque recens linum ostendit non una cicatrix? Nil habet infelix paupertas durius in se, quam quod ridiculos homines facit.

Que dizer do quem dá matéria e motivos de gozações a todos, se a capa está feia e rasgada, a toga já sujinha, se um pé do calçado, rompido o couro, já se abre, ou se mais de uma cicatriz mostre o cordão grosso

qual é difícil resistir. Muitas vezes, irrompe até contra nossa vontade e extrai nossa confissão não só pelo rosto e pela voz, mas também agita todo o corpo com sua força. Como disse, o riso reverte os momentos culminantes, como quando desfaz o ódio e a raiva". 
com que há pouco foi suturado o ferimento?

Nada mais duro carrega consigo a infeliz pobreza

do que aquilo que faz ridículos os homens.

A despeito do fardo que é o ridículo, seria possível, porém, perceber no trecho certa ironia que, atestando pelos signos de pobreza a miserabilidade do pobre, denunciasse tacitamente quiçá a causa pelo efeito. Conceda-se. Todavia, numa expressiva metáfora em que invectiva homossexuais, Juvenal ao vicioso prescreve dorida cura (1, vv. 9-13 e 23-24):

Frontis nulla fides; quis enim non uicus abundat tristibus obscaenis? Castigas turpia, cum sis inter Socraticos notissima fossa cinaedos? Hispida membra quidem et durae per brachia saetae promittunt atrocem animum, sed podice leui caeduntur tumidae medico ridente mariscae. [...]

Loripedem rectus derideat, Aethiopem albus; quis tulerit Gracchos de seditione querentes?

Nada de confiar no rosto; que viela não transborda desses obscenos de ar grave? Castigas a torpeza, quando és o buraco mais conhecido entre os socráticos passivos? ${ }^{16}$ De fato, os cabeludos membros e a dura pelosidade nos braços prometem espírito atroz, mas no ânus depilado túrgidas hemorróidas são extirpadas pelo médico que ri.

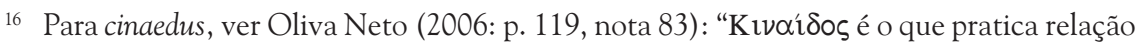

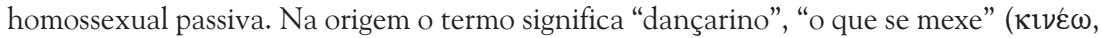
"mover-se"), passando a indicar um tipo de prostituto. "O kináidos, a bem dizer, não é um 'homossexual', nem, porém, uma pessoa comum que vez ou outra decide praticar um ato 'cinédico'. Kináidos era um homem socialmente desviante em todo o seu ser, cujo desvio era observável sobretudo no comportamento que flagrantemente violava e contravinha a definição social dominante de masculinidade. (É claro que é outra questão se, fora das arenas de discurso jocoso ou vituperioso onde se acha o kináidos, houve de fato kináidoi reais)", Winkler (1990: 177). Cinaedus na poesia latina tem acepção semelhante e em Catulo, particularmente, designa o praticante da felação". 
$[\ldots]$

É possível que um homem normal zombe de um coxo, e um branco, de um etíope; mas quem suportaria os Gracos reclamar de sedição?

Tendo elegido a homossexualidade passiva como objeto vicioso a invectivar, o poeta labora no campo semântico doença / medicina. Peludos e másculos nas partes visíveis e ilusores assim dos desavisados, os cinaedi simulam feminilidade por depilar as nádegas, de costume invisíveis. Praticados os atos contra a natureza, a contrariedade manifesta-se pelas conseqüentes hemorróides (mariscae), maladia incidente no ânus (podice, de podex), na parte com que se cometeu a falta. Para efeito de cura, as excrescências são extirpadas, cortadas (caeduntur, de caedere, termo médico, "cortar", como o grego $\tau \dot{\varepsilon} \mu \nu \omega)$ pelo cirurgião, identificado à persona satírica exatamente por meio da inverossímil derrisão. A cirurgia é moral, como a sátira. Punitivo e proveniente de quem cura, o riso incide no paciente/ vicioso e é diretamente proporcional à dor. Para o médico satírico é dor irrisória, decerto porque é alheia. Para o paciente, é riso dolorido, decerto porque é sem graça. Assim, conclui-se que na sátira a cura do morbo social ocorre não por incluir o vicioso, purificado em correto ou virtuoso por uma qualquer mezinha, mas por sua mera amputação. Esse caráter ablativo da sátira de Juvenal, por meio de seu riso específico é o que, por seu turno, a assemelha à espécie luciliânica e distingüe da espécie horaciana. Se ambas as espécies se ocupam da moral, se são assim ambas moralizantes, por reconhecer o vicioso, e se em ambas há ridículo, diferem, por outro lado, pela natureza e fim do ridículo e sobretudo pelo fato de que a sátira horaciana não extirpa o vicioso, mas, tendo-o purificado, busca incluí-lo.

\section{REFERÊNCIAS BibliográficAS}

ARISTÓTELES. Poética. Tradução, comentários e apêndices de E. de Souza. Porto Alegre: Editora Globo, 1966.

. Poética. Tradução e notas de A. M. Valente. Lisboa: Serviço de Educação e Bolsas / Fundação Calouste Gulbenkian, 2004.

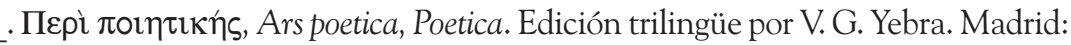
Gredos, 1974.

ARISTOTLE. Poetics. Edited and translated by S. Halliwell. Cambridge/ London: Harvard University Press, 1999. 
. Aristotle's Theory of Poetry and Fine Art. With critical text and translation and commentary of the Poetics by S. H. Butcher. 4 ed. London: 1932.

DE MARTINO, F; VOX, O. La musa e il canto. Antologia di lirici greci. Roma / Bari: Editori Laterza, 1995.

ELSE, G. F. Aristotles's Poetics, the argunment. Cambridge: Harvard University Press, 1967. [1 1 ed. 1957]

FRYE, N. Anatomia da crítica. 2 ed. São Paulo: Cultrix, 1984.

MARTINHO DOS SANTOS, M. "O monstro da Arte poética de Horácio”, Letras Clássicas, São Paulo, n. 4, p. 191-265, 2000.

Oliva NETO, J. A. Falo no jardim, Priapéia grega, Priapéia latina. Cotia: Ateliê Editorial, Campinas: Editora da Unicamp, 2006.

WEST, M. Studies in Greek elegy and iambus. Berlin / New York: Walter de Gruyter, 1974.

WINKLER, J. "Laying down the law: the oversight of men's sexual behavior in classical Athens". In: HALPERIN, D.; WINKLER, J.; ZEITLIN, F. I. (org.). Before sexuality: the construction of erotic experience in the ancient Greek world. Princeton: Princeton University Press, 1990. p. 171-209.

OLIVA NETO, João Angelo. Invective humor or harmless humor: the species of iambus, comedy and satire.

ABSTRACT: The article's goal is to make clear that in Poetics, IV $1448 b, 23-40$ and $V, 1449 a, 32-35$, Aristotle takes for granted the existence of at least two kinds of humor, invective and harmless, which he correlates to the iambus and comedy respectively. On the grounds of Gerald Else's reading and interpretation of those passages (Aristotle's Poetics, the argument, 1967), I try to show that the philosopher subscribes the harmless humor rather than the invective one and how the difference between them produces species in the iambus, comedy and hexametrical satire.

KEY WORDS: Aristotle's Poetics; invective humor; harmless humor; iambus, comedy, satire 